\title{
Green Building Analysis of PT United Tractors on Existing Building Based on the Latest Rating Tools Green Building Council Indonesia
}

\author{
1,2 Bakhtiar Burhan \\ ${ }^{1}$ United Tractors, Cakung - Indonesia \\ ${ }^{2}$ Master of Mechanical Engineering \\ Swiss German University \\ Tangerang City, Indonesia \\ sris@unitedtractors.com \\ Henry Nasution \\ Master of Mechanical Engineering \\ Swiss German University \\ Tangerang City, Indonesia \\ henry.nasution@sgu.ac.id
}

\author{
Hanny J. Berchmans \\ Master of Mechanical Engineering \\ Swiss German University \\ Tangerang City, Indonesia \\ hanny.berchmans@lecturer.sgu.ac.id
}

\author{
Dena Hendriana \\ Master of Mechanical Engineering \\ Swiss German University \\ Tangerang City, Indonesia \\ dena.hendriana@sgu.ac.id
}

Abstract-PT United Tractors building has received a Platinum predicate for the Greenship New Building Category. However, the more advanced the development and growth of the company, research must continue to be done to see if the building is still feasible in its current condition. The method used in this research is to compare the condition of the existing building with the Greenship New Building Assessment tool. After comparisons, a new category suitability analysis was carried out for existing buildings. The analysis was carried out by direct measurement methods, interviews and using secondary data. From the results of the study, the PT United Tractors building received a Gold rating, because it met five building eligibility requirements, including Appropriate Site Development, Energy Efficiency and Conservation, Water Conservation, Material Resources and Cycle, Indoor Air Health and Comfort. The assessment of the suitability of the criteria in each category showed a result of 65 points $(57 \%)$. For this reason, it needs improvement in order to reach the highest point in Platinum rank.

Keywords-green building, greenship, existing building, criteria, points, recommendations.

\section{INTRODUCTION}

UT Head Office in Fig. 1 is the head office building owned by PT United Tractors Tbk which has received a platinum rating in the Greenship New Building ver.1.1 certification. As one of the requirements to maintain the platinum rating, it is necessary to simulate energy saving calculations using calculation and software. In accordance with the provisions of the latest version of Greenship Existing Building ver.1.1, the calculation of energy savings is carried out by obtaining the difference between the annual energy consumption value of the baseline building with the building design and the latest application which is summarized in the existing building along with the acquisition of new renewable energy values.

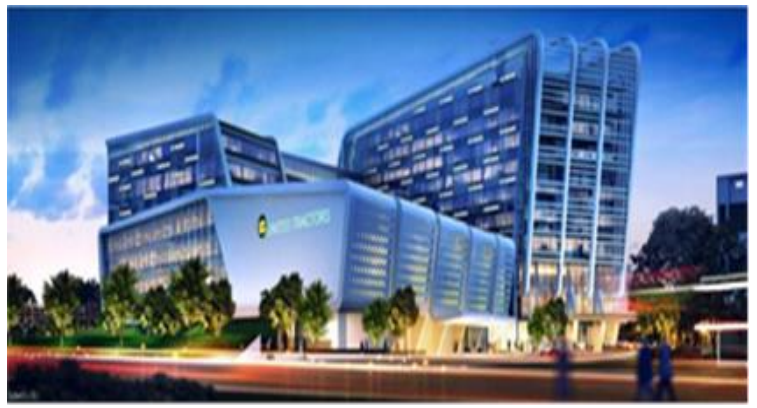

Fig. 1. UT head office building

This study will discuss details about the energy simulation carried out on UT Head Office. For the record, the baseline building has parameters based on the rules and regulations referred to by GREENSHIP. While the design building is a building that has parameters based on the design and planning set by the planner.

The Objectives of this work are:

- Provides information regarding the Green Building concept based on Green Building Council Indonesia (GBCI).

- Analyze the requirement and feasibility of the UT Head Office Building to be able to threaten as ad Green Building.

- Conduct a suitability analysis of the UT Head Office Building based on Green Building Criteria.

- Provide recommendations related to effort to repair the UT Head Office Building to achieve a certified rating. 


\section{LITERATURE REVIEW \& RESEARCH METHODOLOGY}

\section{A. Green Building}

Green building is a building that is planned and implemented immediately by taking into account environmental environmental factors that meet criteria such as land use, energy efficiency and conservation, water conservation, material sources and cycles, health and comfort in space, environmental management.

Green building is a concept that leads to structures and processes by taking into account the environment, from site selection to construction design, operation, renovation, and designation. a concept that complements and expands building design in terms of economy, utility, durability and comfort.

\section{B. Greenship}

Greenship from GBCI has 2 types of rating tools, namely Greenship for existing buildings and new buildings. Based on the standard, there are 7 categories with the achievement of 100 points (100\%), namely Development of Appropriate Locations (17\%), Efficiency and Energy Conservation (26\%), Water Conservation (20\%), Material Resources and Cycles (14)\%), Indoor Health and Comfort (10\%), Environment and Building Management (13\%).

The rating system or benchmarking device is a tool containing items from an aspect of the rating called rating. Each rating has a value (credit point). Benchmarking devices in relation to green buildings are assessment tools that assess a building's rating against the building concept's achievement. GBC Indonesia issues a rating called Greenship.

The four bases are expected to be a trigger for building industry players to implement the green building concept because they do not meet the criteria required in the ranking in obtaining certification. There are four ranks of version 1.1 greenship which later became the target for construction, namely:

TABLE I

GREENSHIP RATING [12]

\begin{tabular}{lcc}
\hline \multicolumn{1}{c}{ Rating } & Minimum Point & $\%$ \\
\hline Platinum & 74 & $73 \%$ \\
Gold / Emas & 58 & $57 \%$ \\
Silver / Perak & 47 & $46 \%$ \\
Bronze / Perunggu & 35 & $35 \%$ \\
\hline
\end{tabular}

\section{Research Methodology}

The research will be carried out in SeptemberDecember 2020 at the Head Office Building of PT United Tractors, Jalan Raya Bekasi KM22, Cakung, East Jakarta. following is the research method of each benchmark carried out. Research instrument used for data collection.
And assessment purposes consist of 2 (two) types, namely:

1. Checklist.

2. Testing equipment.

The compilation of the two research instruments was based on several references, including:

1. Greenship Rating Tools Existing Building

2. National regulations and standards (SNI) related to each of the criteria in the Green Building

3. Some other supporting literature/references

The following are the equipment/instruments used to find out primary data from the existing condition of the building.

TABLE II

NAME OF TOOLS AND INSTRUMENTS IN RESEARCH

\begin{tabular}{|c|c|c|}
\hline No. & Tool / Instrument Name & Function \\
\hline & Hardware & \\
\hline 1 & GPS & $\begin{array}{l}\text { Know the coordinates of the building site for } \\
\text { determine the site plan. }\end{array}$ \\
\hline 2 & Tape Measure & Length measuring tool \\
\hline 3 & Power Logger Analyzer & Measure the quality of el ectricity \\
\hline 4 & Sound level meter & Measure noise levels in office space \\
\hline 5 & Room thermometer & $\begin{array}{l}\text { Measure the air temperature in the office } \\
\text { space }\end{array}$ \\
\hline \multirow[t]{2}{*}{6} & Luxmeter & Measure the level of lighting in an office space \\
\hline & Software & \\
\hline 7 & Autocad Vers.2011 & $\begin{array}{l}\text { Describe the condition of the site / site plan as } \\
\text { well building plans in } 2 \text { dimensions }\end{array}$ \\
\hline 8 & Sketch Up Pro Vers.8 & $\begin{array}{l}\text { Depict buildings in shape } 3 \text { dimensions for the } \\
\text { purposes of calculating OTTV }\end{array}$ \\
\hline 9 & Microsoft Excel & $\begin{array}{l}\text { Processing existing primary and secondary } \\
\text { data specified in the criteria }\end{array}$ \\
\hline
\end{tabular}

The suitability analysis is obtained by comparing the results of the checklist with existing tools, that is the Greenship Rating Tools Existing Building Version 1.1. After adjustments are made, points are obtained for each criterion and then the results are added up into total points and a ranking category will be obtained in GREENSHIP.

Following are the 6 (six) categories of Green Building that will be reviewed for each criterion and benchmark

1. Land Use Category

2. Energy Category Efficiency and Conservation

3. Water Conservation Category

4. Source Category and Material Cycle

5. Indoor Category Health and Comfort

6. Building Environment Category

After analyzing the suitability of the UT Head Office Building with the Greenship Rating Tools Existing Building Version 1.1, it will be known the deficiencies that occur in the field, so that recommendations emerge as an effort to improve the building to increase the value/points of the Green Building so that it can meet the requirement and criteria to reach the rating that are in Greenship. 


\section{Research Flow Chart}

The following is Fig 2 which shows the research flow diagram:

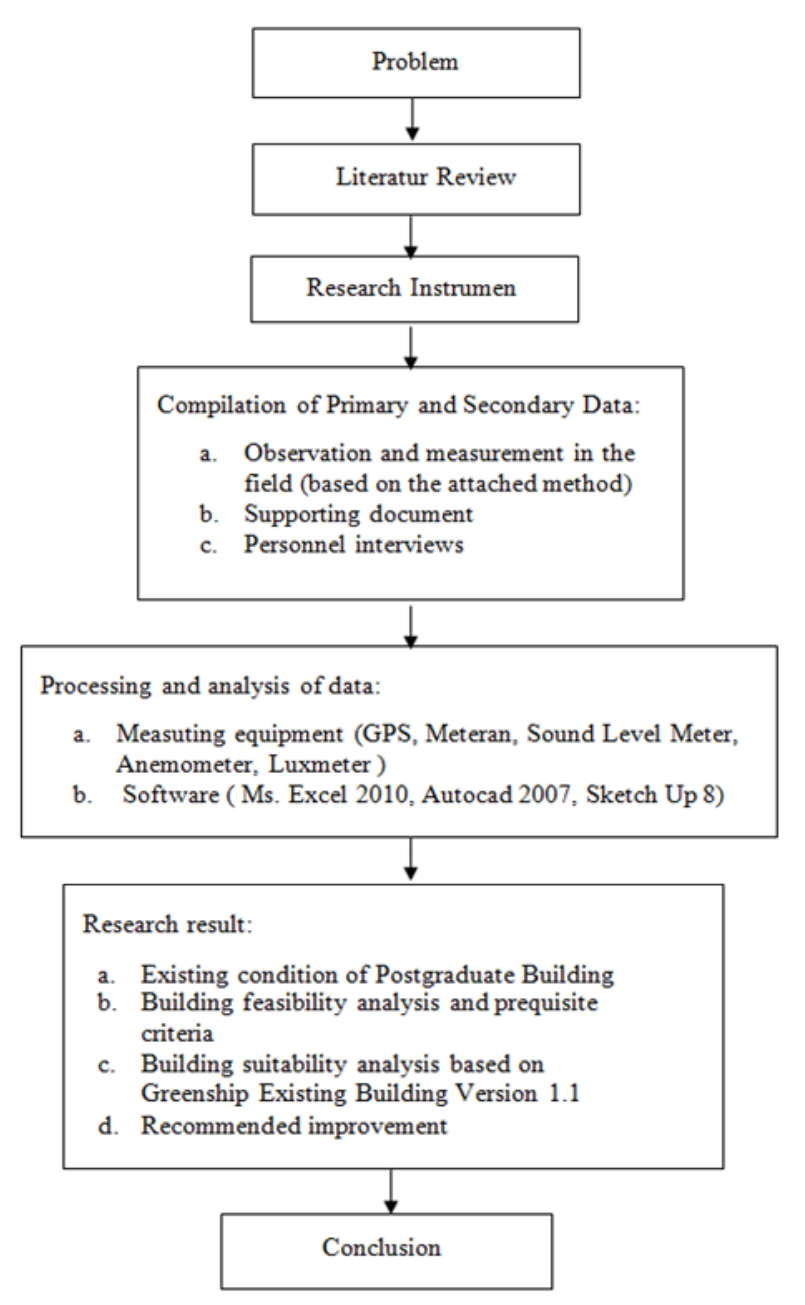

Fig. 2. Research flow diagram

The stages of the research carried out are as follows:

a. Initial survey and application for permission to conduct research

b. Collect various references, data and literature reviews about Green Building

c. Compile research designs and determine research methods

d. Develop research instruments

e. Review and study the implementation of the Green Building in the UT Head Office Building by conducting field observations and measurements for certain criteria, as well as conducting personnel interviews and document evaluation

f. Conduct a study on the feasibility of a building based on the conditions specified in the Greenship Existing Building

g. Conducted a study on the Prerequisite Criteria in Greenship Existing Building Version 1.1 h. Perform processing, data analysis and calculations of several criteria based on the Greenship Rating Tools for Existing Building Version 1.1 with the help of measurement equipment and computer software (Microsoft Excel 2010, AutoCAD 2011, and Sketch Up Pro8)

i. Provide research results in the form of information about the existing conditions of the UT Head Office Building, building feasibility analysis and prerequisite criteria

j. Provide research results in the form of points obtained in existing conditions and gap analysis that appears between existing conditions and Green Building standards

k. Providing recommendations for improvements to the UT Head Office Building as an effort to improve the quality and performance of the building, so that it can achieve good quality as a Green Building

1. Draw conclusions that answer the initial research objectives and provide suggestions

\section{RESULTS}

\section{A. Analysis of Criteria Fit in Greenship}

1. Land Use Appropriate Category

In the appropriate land use category, there are 7 criteria that have a total maximum value of 17 points. After being analyzed from the calculation results in the Appropriate Land Use (ASD) category, several criteria meet the predetermined benchmarks, so that the points obtained are 15 (five teen) points, with the following details:

\begin{tabular}{|c|c|c|c|}
\hline \multirow{2}{*}{ CODE } & \multirow{2}{*}{ CRITERIA } & \multirow{2}{*}{$\begin{array}{c}\text { PROJECT POINT } \\
\text { MAXIMUM }\end{array}$} & \multirow{2}{*}{$\begin{array}{c}\text { PROJECT POINT } \\
\text { ACTUAL }\end{array}$} \\
\hline & & & \\
\hline$\overline{A S D P}$ & Basic Green Area & Prerequisite & Prerequisite \\
\hline ASD 1 & Site Selection & 2 & 1 \\
\hline ASD 2 & Community Accesbility & 2 & 2 \\
\hline ASD 3 & Public Transportation & 2 & 2 \\
\hline ASD 4 & Bicycle & 2 & 2 \\
\hline ASD 5 & Site Landscaping & 3 & 2 \\
\hline ASD 6 & Micro Climate & 3 & 3 \\
\hline \multirow[t]{2}{*}{ ASD 7} & Storm Water Management & 3 & 3 \\
\hline & & 17 & 15 \\
\hline
\end{tabular}

2. Energy Category Efficiency and Conservation

In this category, there are 5 (five) criteria that have a total maximum score 26 points. After being analyzed from the calculation result, so that the point obtained are 17 (seventeen) point, with the following details:

\begin{tabular}{|c|c|c|c|}
\hline \multirow{2}{*}{ CODE } & \multirow{2}{*}{ CRITERIA } & \multirow{2}{*}{$\begin{array}{c}\text { PROJECT POINT } \\
\text { MAXIMUM }\end{array}$} & \multirow{2}{*}{$\begin{array}{c}\text { PROJECT POINT } \\
\text { ACTUAL } \\
\end{array}$} \\
\hline & & & \\
\hline EEC P1 & Electrical Sub Metering & Prerequisite & Prerequisite \\
\hline EEC P2 & OTTV Calculation & $\mathrm{P}$ & $P$ \\
\hline $\mathrm{EEC} 1$ & Energy Efficiency Measure & 20 & 11 \\
\hline $\mathrm{EEC} 2$ & Natural Lighting & 4 & 4 \\
\hline $\mathrm{EEC} 3$ & Ventilation & 1 & 0 \\
\hline $\mathrm{EEC} 4$ & Climate Change Impact & 1 & 1 \\
\hline \multirow[t]{2}{*}{ EEC 5} & On Site Renewable Energy & 5 & 0 \\
\hline & & 31 & 17 \\
\hline
\end{tabular}


3. Water Conservation and Material Cycle

In this category, there are 6 criteria that a total maximum score 21 point. After being analyzed from the calculation result, so that the point obtained are19 point, with the following details:

\begin{tabular}{|c|c|c|c|}
\hline \multirow{2}{*}{ CODE } & \multirow{2}{*}{ CRITERIA } & \multirow{2}{*}{$\begin{array}{c}\text { PROJECT POINT } \\
\text { MAXIMUM } \\
\end{array}$} & \multirow{2}{*}{$\begin{array}{c}\text { PROJECT POINT } \\
\text { ACTUAL } \\
\end{array}$} \\
\hline & & & \\
\hline WACP1 & Water Metering & Prerequisite & Prerequisite \\
\hline WACP2 & Water Calculation & Prerequisite & Prerequisite \\
\hline WAC 1 & Water Use Reduction & 8 & 8 \\
\hline WAC 2 & Water Fixture & 3 & 3 \\
\hline WAC 3 & Water Recycling & 3 & 3 \\
\hline WAC 4 & Alternative Water Resource & 2 & 1 \\
\hline WAC 5 & Rainwater Harvesting & 3 & 3 \\
\hline \multirow[t]{2}{*}{ WAC 6} & Water Efficiency Landscaping & 2 & 1 \\
\hline & & 21 & 19 \\
\hline
\end{tabular}

\section{Material Resources and Cycle Category}

In this category, there are 6 criteria that a total maximum score 14 point. After being analyzed from the calculation result, so that the point obtained are 9 point, with the following details:

\begin{tabular}{|c|c|c|c|}
\hline \multirow{2}{*}{ CODE } & \multirow{2}{*}{ CRITERIA } & \multirow{2}{*}{$\begin{array}{c}\text { PROJECT POINT } \\
\text { MAXIMUM } \\
\end{array}$} & \multirow{2}{*}{$\begin{array}{c}\text { PROJECT POINT } \\
\text { ACTUAL } \\
\end{array}$} \\
\hline & & & \\
\hline MRC P & Fundamental Refrigerant & Prerequisite & Prerequisite \\
\hline MRC 1 & Building and Material Reuse & 2 & 0 \\
\hline MRC 2 & Environmentally Processed Product & 3 & 2 \\
\hline MRC 3 & Non ODS Usage & 2 & 2 \\
\hline MRC 4 & Certified Wood & 2 & 2 \\
\hline MRC 5 & Prefab Material & 3 & 2 \\
\hline \multirow[t]{2}{*}{ MRC 6} & Regional Material & 2 & 1 \\
\hline & TOTAL & 14 & 9 \\
\hline
\end{tabular}

\section{Indoor Health and Comfort Category}

In this category, there are 7 criteria that a total maximum score 10 point. After being analyzed from the calculation result, so that the point obtained are 5 point, with the following details:

\begin{tabular}{|c|c|c|c|}
\hline \multirow{2}{*}{ CODE } & \multirow{2}{*}{ CRITERIA } & \multirow{2}{*}{$\begin{array}{c}\text { PROJECT POINT } \\
\text { MAXIMUM } \\
\end{array}$} & \multirow{2}{*}{$\begin{array}{c}\text { PROJECT POINT } \\
\text { ACTUAL } \\
\end{array}$} \\
\hline & & & \\
\hline $\mathrm{IHCP}$ & Outdoor Air Introduction & Prerequisite & Prerequisite \\
\hline $\mathrm{IHC} 1$ & $\mathrm{CO} 2$ Monitoring & 1 & 0 \\
\hline $\mathrm{IHC} 2$ & Environmental Tobacco Smoke Control & 2 & 2 \\
\hline $\mathrm{IHC} 3$ & Chemical Pollutants & 3 & 1 \\
\hline $\mathrm{IHC} 4$ & Outside View & 1 & 1 \\
\hline $\mathrm{IHC} 5$ & Visual Comfort & 1 & 0 \\
\hline $\mathrm{IHC} 6$ & Thermal Comfort & 1 & 1 \\
\hline \multirow[t]{2}{*}{ IHC 7} & Acoustic Level & 1 & 0 \\
\hline & TOTAL & 10 & 5 \\
\hline
\end{tabular}

\section{Environment and Building Management Category}

In this category, there are 7 criteria that a total maximum score 13 point. After being analyzed from the calculation result, so that the point obtained are 5 point, with the following details:

\begin{tabular}{llcc}
\hline \multirow{2}{*}{ CODE } & \multicolumn{1}{c}{ CRITERIA } & PROJECT POINT & PROJECT POINT \\
\cline { 3 - 4 } & & MAXIMUM & ACTUAL \\
\hline BEM P & Basic Waste Management & Prerequisite & Prerequisite \\
BEM 1 & GP as a Member of The Project Team & 1 & 0 \\
BEM 2 & Pollution of Construction Activity & 2 & 0 \\
BEM 3 & Advanced Waste Management & 2 & 0 \\
BEM 4 & Proper Commisioning & 3 & 0 \\
BEM 5 & Green Building Data Submission & 2 & 0 \\
BEM 6 & Fit out Agreement & 1 & 0 \\
BEM 7 & Occupant Survey & 2 & 0 \\
\hline & & $\mathbf{1 3}$ & $\mathbf{0}$ \\
\hline
\end{tabular}

\section{B. Comparison Before Audit and After Audit}

From the result below, there is a difference between the audit assessment carried out before this research began, using the Greenship New Building version 1.0 tools with the Greenship Existing Building version 1.1 tools

\begin{tabular}{clccc}
\hline No. & Greenship Category & Greenship Point & $\begin{array}{c}\text { Greenship } \\
\text { New Building }\end{array}$ & $\begin{array}{c}\text { Greenship Exsiting } \\
\text { Building }\end{array}$ \\
\hline & \multicolumn{1}{c}{ Maximum } & Actual & Actual \\
\hline 1 & $\begin{array}{l}\text { Appropriate Site } \\
\text { Development }\end{array}$ & 17 & 15 & 15 \\
2 & $\begin{array}{l}\text { Energy Efficiency \& } \\
\text { Conservation }\end{array}$ & 26 & 16 & 17 \\
3 & $\begin{array}{l}\text { Water Conservation } \\
\text { Material Resources and }\end{array}$ & 14 & 19 & 19 \\
4 & $\begin{array}{l}\text { Cycle } \\
\text { Indoor Health and }\end{array}$ & 10 & 8 & 9 \\
5 & $\begin{array}{l}\text { Comfort } \\
\text { Building Environment } \\
\text { \& Management }\end{array}$ & 13 & 10 & 5 \\
\hline \multicolumn{1}{c}{ TOTAL } & 101 & 74 & 65 \\
\hline
\end{tabular}

\section{CONCLUSION AND RECOMMENDATIONS}

\section{A. Conclusion}

- $\quad$ Received a GOLD PREDICATE after conducting research based on tools from Greenship Existing Building version 1.1

- Building has now implemented the green building criteria as specified in the Existing Greenship assessment tool. However, indirectly, several benchmarks have not been implemented.

- Based on the analysis of 7 building feasibility requirements, the UT Head Office Building has met all the requirements, including site area, IMB availability, building suitability to spatial planning, building suitability to safety standards for fire and earthquake resistance.

- Based on the analysis of 7 building feasibility requirements, the UT Head Office Building has met all the requirements, including site area, IMB availability, building suitability to spatial planning, building suitability to safety standards for fire and earthquake resistance. 
- Based on the analysis, of the 6 categories meet the prerequisites, namely the category Appropriate for Land Use, Material Sources and Cycles, Health and Comfort in Space and Environmental and Building Management, the category of Energy Efficiency and Conservation and Water Conservation.

- $\quad$ Based on the results of the analysis, of the 38 criteria in the category, the UT Head Office Building received a total of 65 points, so it is included in the criteria for a Green Building with a Gold rating.

\section{B. Recommendation}

Recommendations that can be made to meet Platinum criteria in green buildings are as follows:

- Increase and utilize solar energy with photovoltaics technology with a capacity of 1000 kilowatts.

- Replacing the San Ei brand wall faucet whose output capability is above the maximum standard, with energyefficient faucets, so that savings can reach $30.03 \%$

- $\quad$ Provide $\mathrm{CO} 2$ gas sensors in high density rooms

- Optimizing the lighting during lectures and increasing the number of lights in the library so that the lighting level reaches a predetermined standard.

\section{REFERENCES}

[1] R Qiao and T. Liu, Impact of Building Greening on Building Energy Consumption, 2019.

[2] B. C. Xie, Assessment of Energy and Emission Performance of a Green Scientific Research Building in Beijing, China, 2020.

[3] L. Wang and O. Zhen, Integrated Analysis of Energy, 2011.

[4] American Concrete Pavement Association, Albedo: A Measure of Pavement Surface Reflectance. Lawrence Berkeley National Laboratory, 2002.

[5] Badan Standarisasi Nasional, SNI 03-6389-2011 Tentang Konservasi Energi Selubung Bangunan pada Bangunan Gedung, Badan Standarisasi Nasional: Jakarta, 2000.

[6] Badan Standarisasi Nasional, SNI 03-6390-2011 Tentang Konservasi Energi Sistem Tata Udara pada Bangunan Gedung, Badan Standarisasi Nasional: Jakarta, 2000.

[7] Badan Standarisasi Nasional, SNI 03-6386-2000 Tentang Spesifikasi Tingkat Bunyi dan Waktu Dengung dalam Bangunan Gedung dan Perumahan, Badan Standarisasi Nasional: Jakarta, 2000.

[8] Badan Standarisasi Nasional, SNI 03-7065-2005 Tentang Tata Cara Pelaksanaan Sistem Plambing, Badan Standarisasi Nasional: Jakarta, 2005.

[9] D. Chiras, The Homeowner's Guide to Renewable Energy, New Society Publishers: Canada, 2006

[10] W. I. Ervianto, Selamatkan Bumi Melalui Konstruksi Hijau, Penerbit ANDI, Yogyakarta, 2012.

[11] Green Building Council Indonesia, Panduan Penerapan Perangkat Penilaian Bangunan Hijau GREEENSHIP Versi 1.0, Green Building Council Indonesia: Jakarta, 2010.

[12] Green Building Council Indonesia, Greenship Rating Tools Untuk Gedung Terbangun Versi 1.2, Green Building Council Indonesia: Jakarta, 2013.

[13] G. H. Kats, Green Building Cost and Financial Benefits, Massachusetts Technology Collaborative, 2003.

[14] H. André de, B. Façade, F. Somfy, and S. Loekita, "Analisis konservasi energi melalui selubung bangunan," Civil Engineering Dimension, 8, 2006. 